va a todos nós de forma gentil. Era capaz de perceber em nossas dúvidas, um potencial transformador que nos animava e afetava, nos comprometendo com o fazer e agir em atos.

Arrisco afirmar que, é impossível pensar a história da Psicologia Social no Brasil e na América Latina sem trazer a identidade viva, doce, humana, persistente, combativa e critica intransigente das idéias positivistas e conservadoras. Por sua ação constante, Bader Sawaia a cita como "psicóloga da ação política”. Sílvia Lane construiu bons encontros a moda espinosana: alegres e éticos. E plantou sonhos possíveis em todos nós. Foi uma mulher em movimento. Certamente, ela habitará para sempre, nossos corações de estudantes, pesquisadores, professores e leitores. Professora Sílvia Lane, para sempre, você estará PRESENTE.

\section{Notas}

${ }^{1}$ Termo usado por marx, cujo significado é: "Animal político". Marx, K. Textos escolhidos e anotados. Do Homem Alienada à Sociedade Comunista. Lisboa: Editorial notícias, 1978.

Margarida Barreto é médica e doutora em Psicologia Social. Atualmente trabalha no Sindicato dos Trabalhadores nas Indústrias Químicas e Plásticas de São Paulo. Endereço para correspondência: Rua Tamandaré, 348, $3^{\circ}$ andar, Liberdade, São Paulo, SP. megbarreto@uol.com.br

\title{
A SIMPLICIDADE COMPETENTE
}

\author{
Ana Lúcia Artioli \\ Universidade do Estado de Mato Grosso, Campo Grande, Brasil
}

As impressões que tenho sobre a Sílvia Tatiana Maurer Lane se dão em dois sentidos: o primeiro com as leituras das produções teóricas e o segundo com a convivência durante as reuniões do Núcleo ou de orientação de tese.

Ao ler os inúmeros textos da Sílvia Lane algumas observações consigo fazer:

São textos caracterizados por uma diversidade de temas, marcados por uma solidez teórica, extrema clareza e de interesse a todos os envolvidos na Psicologia Social e áreas afins.

Outra questão que merece destaque é a coragem da autora em discutir e refletir sem preconceito em seus trabalhos os estudos realizados por autores de diferentes concepções teóricas sem, no entanto, contradizer em momento algum a sua base epistemológica materialistahistórica e dialética, demonstrando um vasto conhecimento que lhe possibilitou esse passeio teórico.

Alguns textos podem parecer repetitivos entre si em alguns momentos, entretanto, eles sempre avançam sobre a idéia já colocada e redimensionam para uma nova reflexão abrindo novos caminhos de compreensão sobre a teoria sócio-histórica.

Tão importantes quanto os textos produzidos, publicados ou não, foram as conversas com a Sílvia. Ela tinha uma ação compatível com o que falava e escrevia. Nas oportunidades de discussão no núcleo, as conversas, as explicações, as explanações eram dadas com a segurança e tranqüilidade de quem não precisa se apegar aos livros para falar a respeito. Ela, além de dominar o assunto, os vivia também com coerência e simplicidade de quem não está preocupada em se auto-afirmar. Os inúmeros exemplos dados para garantir a nossa compreensão eram do nosso dia-a-dia, fazendo-nos ver a teoria acontecendo no nosso cotidiano histórico. Além disso, essas explicações não eram dadas com um linguajar formal, pelo contrário, a vivência da teoria fazia com que a fala seguisse o mesmo curso das conversas informais. Assim, me sentia e acredito que os demais colegas também, completamente à vontade nas nossas reuniões, pois as dúvidas que levantávamos a partir do texto lido para discussão, por mais elementares que fossem, ela as considerava como sumamente importantes e os respondia atentamente. As faltas da Sílvia nas reuniões do núcleo eram, obviamente, sentidas, mas mantínhamo-nos reunidos porque sabíamos que nos próximos encontros com a sua presença as discussões seriam de uma riqueza infinita.

O meu enorme respeito pela Sílvia se dá pela pessoa simples e extremamente competente que ela se nos apresentou. Ela era firme, mas não autoritária, condição que me levava a ficar ainda mais empolgada com a minha pesquisa, pois sem me sentir pressionada ficava 
com muita vontade de levar adiante o meu trabalho de tese.

Ela foi uma orientadora, amiga, transparente, doce, sem perder a firmeza e a profundidade teórica até os seus últimos dias de vida. Sinto saudades!
Ana Lucia Artioli é psicóloga, doutoranda em Psicologia Social. Professora Assistente do Departamento de Pedagogia da Universidade do Estado de Mato Grosso (UNEMAT). Endereço para correspondência: Avenida São João, s/n, Cavalhada, Cárceres, MT, 78200-0000. pedagogia_cac@unemat.br 